\title{
Chapter 11 \\ Zagreb: Parents in Action-Innovative Ways of Support and Policies for Children, Women and Families
}

\author{
Gojko Bežovan, Jelena Matančević and Danijel Baturina
}

\subsection{Introduction}

Unlike the social policies in the majority of other Croatian cites, the social policy in Zagreb is often referred to as comprehensive and generous. The core of social policy of the city is a set of diverse social assistance measures (benefits), covering a wide range of beneficiary groups, whereas social services can be regarded as less developed. However, those fields neither seem to build up a coherent system nor do they have a strategic policy orientation. Nevertheless, over the past decade, there has been a noticeable development of local (public) services and recognition of new vulnerable social groups. The examples are services for the homeless, public kitchens, shelters for victims of domestic violence, disabled people, etc. The problem of insufficient coordination between different city departments and the lack of professionals' comprehension of a wider social system is very visible. Developmental challenge of social care system identified as coordination of government and city social programmes has not been properly addressed in policy papers yet (Bežovan 2009; Bežovan and Zrinščak 2001). Bearing in mind population coverage and the levels of social rights, it can be said that Zagreb serves almost as a "local welfare state" due to its stable budget, which provides generous and comprehensive social programmes. Owing to that, even civil society can get more funds from the city budget.

The concept of social innovation, its meaning and understanding in the general public and even within the academic community, is rather new and vague. There is a scarcity of policy and academic papers that deal with social innovations. Civil

\footnotetext{
G. Bežovan $(\bowtie) \cdot J$. Matančević $\cdot$ D. Baturina

Institute for Social Policy, Faculty of Law, University of Zagreb, Nazorova 51,

10000 Zagreb, Croatia

e-mail: gojko.bezovan@pravo.hr

J. Matančević

e-mail: jelena.matancevic@pravo.hr

D. Baturina

e-mail: danijel.baturina@pravo.hr

(C) The Author(s) 2016

T. Brandsen et al. (eds.), Social Innovations in the Urban Context,

Nonprofit and Civil Society Studies, DOI 10.1007/978-3-319-21551-8_11
} 
society organisations seem to be more receptive to the concept, which has slowly started to permeate the civic discourse. Also, recent research (Bežovan 2009, 2010) on the roles and contribution of local stakeholders to development of welfare mix has shown that civil society organisations (CSOs) are more familiar with the social innovations concept than state organisations.

Identified social innovations in Croatia reveal some particular characteristics of development and diffusion. Firstly, there is the importance of social and cultural capital. Mutual trust and engagement of the better-off and better-educated citizens are an important prerequisite for the success of innovation. It was also shown that personal capacity and entrepreneurial orientation of the initiators, who are often inspired by ideas or movements from abroad, play an important role. Such civic entrepreneurs, as Goldsmith explains, can act as catalysts for transformative change (Goldsmith et al. 2010). Secondly, particular innovations are seen as a part of Europeanisation process, which creates new programmatic and financial frameworks for development of innovations. Thirdly, since social innovations in Croatia predominantly occur within civil society, their success and sustainability largely depend on the sensibility and professional capacities of policymakers and public officials, as well as their support.

This chapter presents the case of the CSO Roditelji u akciji-Parents in Action (RODA), which is perceived as innovative in the field of childcare. The innovative dimension of RODA is twofold. On the one hand, it has developed over time into a prominent stakeholder of family policy in Croatia, which has shifted the family matters from the realm of "private" and put them on the public agenda. Secondly, in terms of service production, RODA has evolved from the advocacy to production, and they are now recognised as a good example of social entrepreneurship as an emerging practice in Croatia.

The case study is conducted on the basis of desk research, interviews with the key stakeholders from RODA and a focus group on social innovations in Zagreb.

The Context of Family Policy As for the family policy in Croatia, it is manifested mostly through material benefits, such as children's allowances, tax reliefs and maternity leaves, rather than through provision of services for children. To some extent, this is related to the structure of traditional family: Women used to work less, while relatives and members of extended families used to be on hand. The lack of childcare services is particularly evident in large cities, where nurseries and kindergartens often cannot accommodate the children of working parents (Zrinščak 2008; Dobrotić et al. 2010). The coverage of children aged $3+$ in kindergartens is $55 \%$ on average in Croatia, which is below the coverage of most EU member states, while the coverage of children under 3 with nurseries programme is 19\% (Matković and Dobrotić 2013). Due to insufficient institutional capacities, informal and unpaid family support is still a widespread strategy of ensuring childcare.

At the same time, the research suggests that Zagreb might have a more developed infrastructure of (formal) support to parents, since the survey of the quality of life has shown that respondents from Zagreb reported problems of reconciling work and family lives to a lesser degree. It should be stressed, however, that the coverage 
of children in kindergartens (aged 3-4) in Zagreb and the Zagreb County is above $68 \%$, which is at the same time the greatest share among all counties in Croatia (Dobrotić 2007; Dobrotić et al. 2010).

According to the National Family Policy Strategy (2003), an increase in the number of childcare institutions and increase in the number of children covered with organised preschool care and education was one of the priority areas for family policy development. This strategy also proposed measures related to education and training of parents, incentives for implementation of programmes of civil organisations, educational programmes that include education on family, partnership, parenthood, etc. It was pointed out that family policy should therefore contribute to creating a friendly, social environment, which would help families solve a variety of problems, first and foremost the ones related to children's development. The problem of accommodation of children in preschool institutions becomes a part of national public debates only occasionally, as this is the service that is under the responsibility of local authorities. Rarely have there been cases of protests or highlighting problems in ways that would capture wide public attention. The practice of parent associations and their organised efforts to improve the provision of childcare services as beneficiaries were almost non-existent before. RODA was one of the first CSOs in that still generally underdeveloped area and became the most prominent one. The issue of placing children in nurseries and kindergartens in $\mathrm{Za}$ greb would usually appear on the agenda in early autumn only, when some children would be left without a place in a kindergarten. Due to the pressure of extensive numbers of children not enrolled, the number of private kindergartens and different forms of informal playrooms has increased significantly.

The childcare policy in Zagreb has been one of the high political interests in recent years, with frequent changes regarding financial aspects, as well as the field of value-loaded discussions. It is also a policy field that has mobilised different stakeholders, and it is one of the rather exceptional examples of the mobilisation of service users (parents) for advocacy regarding local welfare policies.

\subsection{RODA}

The association RODA — Parents in Action-was founded in mid-2001, as a spontaneous reaction of parents, women with children, who raised their voices against reduction in maternity allowance and protested in front of the government office. The women connected through the Internet. The association continued to advocate the rights of parents persistently until the maternity allowance was increased and the maternity leave became longer and more flexible.

With its innovative programme of activities, the association was formed in the social space that was previously considered private, and in traditional societies perceived as the responsibility of parents and their extended families. The need for such an initiative came with the increase in number of young families with children, with better education, in a big city (Zagreb), who do not have the support of parents 
and close relatives and still face the challenge of reconciling professional and family commitments. Initially, the efforts of the association centred on the protection of vested social rights, but owing to a lot of volunteer work and enthusiasm, the initiative resulted in multidimensional social change and social innovation.

\subsubsection{Internal Organisation and Modes of Working}

The activities of the association are mainly financed through the state and city programmes which support civil society. Citizens have been participating with smallscale donations, while a company donated 100,000.00 HRK (about 13,150.00 €) to RODA instead of giving out the money for Christmas cards and gifts. RODA also receives various kinds of nonmonetary assistance, and they are allowed to use a storage space free of charge. Initially, they decided not to accept donations from companies that violate the International Code of Marketing of Breast Milk Substitutes, tobacco and pharmaceutical industries and the companies using unethical marketing targeting children. Despite the various sources of support, the activities of RODA rely mostly on voluntary engagement of members.

The deep involvement of RODA in active parenting initiatives has resulted in a social entrepreneurship project of sewing and selling cloth diapers and connected products. Since 2004, RODA has been promoting the use of cloth diapers as a healthier, more environmental friendly and cheaper solution, and they launched the whole venture in 2006. With the production of cloth diapers, RODA has set an example of social entrepreneurship among associations. A high-quality product made from natural materials, healthy and safe for children, is manufactured, while disabled and difficult-to-employ persons are involved in the production. The production facilities are established within Vocational High School in Varaždin, and there are 56 women working there. Social entrepreneurship is sustainable, it brings profit to the association, develops and expands and creates new jobs. The profits generated are reinvested in the business and core activities of the organisation. The association has recently established a limited liability company for further production of cloth diapers.

RODA has 12 branches throughout Croatia, and they have organised various activities in more than 50 cities and towns in Croatia. What now exists is a strong network embedded in society, which is the voice of advocacy for social change.

In order to strengthen its mission and public acceptance, every year RODA gives out awards to the relevant stakeholders who have contributed to fulfilling the mission of their organisation within the society. They also give out a kind of anti-award to those who have been prominent in their negative approach to the vision of the association. In 2011, this anti-award went to the Croatian Minister of Health, who had advocated a restrictive law on medically assisted reproduction.

RODA is known to the wider public through the RODA forum, which has over 40,000 monthly visits. This is the platform where new members with new ideas appear, and they contribute to strengthening the community spirit of the association 
and its constant renewal. This usually refers to the first experience of membership in an organisation and first experience of volunteering. New members always have the time and passion to volunteer and help the others, and they also develop their own character in that way: It is not only about giving, but also receiving to a great extent. Advising other people is a completely new experience for them - to have a feeling that they help the others and that others believe them. These are solid foundations of a sustainable social network ready to take on the new challenges.

The main organising principle is that the association is managed like a household, with better-educated members: $95 \%$ of them have never been members of any associations before. Ideas and projects belong to the association, while volunteer work builds trust and the atmosphere in which members are accepted and respected and they enjoy support of others.

The fact is that these are the middle-class persons who are quite well off, and none of them receives income-tested children's allowance, so the association is not concerned with this topic. Their members are a specific group with similar background, which directs their interests and values to a certain extent. This is why they often cannot perceive the position and priorities of low-income mothers. In this case, civic initiative produced in the CSO belongs to well-off families from young generation exclusively.

The dynamics of social innovation remains visible here through the provision of services: There are tangible and recognisable results. However, advocacy activities are harder to see and they provide long-term results. These two processes and priorities in the association are intertwined. As an association, RODA keeps changing as the children grow up, and this is something that will be interesting to follow in the future. It is simply the dynamics that is difficult to predict. We are talking about a sense of membership in the network in which women share the same or similar values. This is the support that many people need in their lives. The strength and substance of the women is felt in the association. Interestingly enough, none of the politicians has approached the association or expressed direct interest in their work. ${ }^{1}$ It might be seen as a critical issue in terms of governance and perception of this group among politicians as the "opposition". Although they are regularly financed by the state due the quality of their projects, they are not sufficiently recognised by politicians for their actions, and the politicians do not perceive them as strategic partners in policy making. This witnesses to weak capacity of politicians and fragmentation of society.

However, RODA operates in a society where too many people remain silent about things that bother or disturb them; they do not protest, they were raised to obey. If they seek changes, they have to speak publicly about it: The service providers will hear them in one way or the other. What is announced publicly always has a certain resonance. Through such public speech and statements, RODA has become

\footnotetext{
${ }^{1}$ However, in the case of discussion on the increase in prices for children daycare, some stakeholders felt that civil society organizations were happy to come under the umbrella of political parties, this association included, as it meets their interest.
} 
a recognisable stakeholder in the family policy, which improves the quality of programmes for children, their accommodation and diet.

Adequate levels of trust and promoted norms and values are shared by all members of the association, especially the ones practicing volunteer work. In that way, the contribution to social capital multiplication has been made, as a basis for social innovation in the association and beyond. "Mobilisation and organising around a shared vision of change" (Moulaert and Mehmood 2013, p. 448) is an added value of this innovation. In this case, social change is visible in an area that used to be the area of privacy and the space of few government services. It was a framework for social innovation that strengthened the social cohesion in general public.

RODA has passed their knowledge and skills to the organisations in South East Europe, in Sarajevo, Belgrade and other cities. However, it has been impossible to implement such a programme in these countries, as there is neither willingness nor need for volunteer work. So in this case, it can be clearly stated that social innovation emerged from civil engagement and volunteer work of citizens, as a kind of collective action (Habisch and Loza Adaui 2013), making effort to protect and promote their interests.

\subsubsection{Concepts and Ways of Addressing Users}

By promoting and advocating the rights of children, RODA has impacted changes in public policies for children, women and families. Through their consistent cooperation with the media, they have made a recognisable influence on public opinion and lobbied for changes in childcare. For the first time in public policy, being involved in a copayment scheme, they come up with the image of the services co-producer, having vested in the quality of service for which they are paying. RODA encourages active and responsible parenting through direct support and assistance to parents, equipping them with skills and knowledge, empowering them and making them better advocates of the rights of their children. They are joined and networked, which makes them strong and decisive in their public statements.

Parents are the ones who make decisions about their children. The children do not belong to the institutions, but parents can affect the quality of services that children receive in childcare institutions.

RODA has become an important stakeholder in the debate on the right to adequate maternity allowance and maternity leave, the right to medically assisted reproduction, pregnancy and improving birthing conditions, as well as promotion, education and counselling on breastfeeding, education and support to parents and children safety in traffic.

The association has gradually developed into some kind of a "union of parents". They have created a new paradigm of parenting in Croatia, promoting the idea that children need their parents and their greater affection. This kind of attachment parenting is based on emotions and first experience of parenthood. "When you do not have a family to help you, you turn to those similar to yourself." 
RODA is familiar with the problems of many parents barely surviving, seeking their help: They state the cases of families of five who live in apartments of $26 \mathrm{~m}^{2}$. The housing situation is a limiting factor in the expansion of families and the decision to have two or more children. Temporary, 1-year employment contracts also present certain constraints. The association has helped some families to cover delayed rent payments.

For 8 years, RODA has been providing support and advice on breastfeeding through their breastfeeding hotline. They have also organised a school of breastfeeding, a conference and printed and distributed relevant materials. These activities become a strong lever for the social integration of young mothers. This innovation can be studied also as gender and parenthood relations about social arrangement and capacity to organise daily life (André 2013, pp. 414-415).

Considering the vulnerability of children in their parents' cars, RODA launched an initiative for proper use of car seats for children. The result of the initiative was the increase in the number of children who are driven in car seats, as well as in the proportion of car seats that are correctly installed and used appropriately. In the framework of this programme, a large number of brochures have been printed and good cooperation with the police has been established, in so far as they organised quick traffic controls near kindergartens and on the city roads.

Four times a year, RODA organises sales of second-hand children's clothing, shoes and equipment. So far, 30 sales were held, and each was visited by an average of 800 parents. Organising such a 3-day event requires the help of 40 volunteers.

As the children of parents belonging to this association grow up, RODA might develop programmes for teenagers in the scope of its future activities.

\subsubsection{Interaction with the Local Welfare System}

As a well-known stakeholder and advocate of social services for children, RODA had an impact on the practice of making and implementing childcare policy in Zagreb. In partnership with other organisations, they have exerted pressure on the city administration to organise a special session of the Committee for Education and Sports, the body of the City Council, the topic being the prices of childcare services in Zagreb. Instead of paying for the cost of services on the income-test basis, they insisted parents should be means-tested (income, property, etc.). Raising the issue of the means test as a prerequisite for eligibility to social rights is a big and important thing in the national social welfare system. With such impact, the proposal of increasing the cost for such services on an income-test basis has not been accepted. ${ }^{2}$

Also, RODA put on the agenda the issue of quality of childcare services in terms of space per child in kindergartens, quality of food for children and educational programmes. In representing users of services, they are very much respected as a stakeholder, and they are gradually witnessing a process of quality service improvement.

\footnotetext{
${ }^{2}$ At that time, there was strong opposition to the Mayor in the City Council.
} 
After RODA's actions, CSOs of parents have become a visible part of the governance structure of the local welfare system, which made the local welfare system more vibrant and responsive to the public and, specifically, to beneficiaries of social services. As the media were covering all debates and events, the general public got a sense of importance of CSOs and, in this case, of self-organised mothers.

For the first time, this case opened a debate on public issues where citizens have vested interests and showed strengths of a civil organisation addressing public issues and influencing policy process. With this experience, a new culture of communication and relationship of the city with CSOs might be seen.

\subsection{Conclusions}

In transitional countries, civil society is a space for the self-organisation and mobilisation of citizens to protect and to promote their interests. Civic norms, values and networks produce a necessary level of social capital to build trust among local stakeholders and to strengthen social cohesion.

In this case, there existed a fertile soil for social innovations and, after a certain period of time, social entrepreneurship. RODA was established as a successful social innovation because it was in possession of certain social capital mostly from middle class citizens that were its key actors. Also, they were among the first organisations that actively worked in family policy area counting on engagement of families. They became recognised and branded themselves so they are now the organisation that almost every mother has heard about, which contributes to their success as social innovation. It is obvious that developmental capacity of this innovation, being owned by a civic organisation, increases on a steady basis.

Empirical evidence says that civil society is a space for self-organisation and selfpromotion of the middle class, which is the core of "urban citizenship". It brings the issue of fragmentation of the space of civil society as a relevant topic for further research. Important question is the one of capacities and inequalities. What are the differences in possibilities of organisations with developed social connections and social capital derived from their middle class status as opposed to the organisations founded by lower class citizens? Also, what are the differences between urban and rural based organisation?

The case made impact on the local and national welfare systems in terms of policy making process and governance producing new welfare culture in this field. Besides such promising development of the analysed social innovation in the space of civil society, the social welfare system, which is in the hands of government and the city, has still not become the space of viable social innovations. Overregulation and paternalistic style of government, where the authorities own public policy, remains the major obstacle for developing social innovations (Bežovan et al. 2013). Some earlier research (Bežovan 2010) identifies the problems of a lack of coordination and poor cooperation between different local stakeholders. Mobilisation of local stakeholders and facilitation of social change appears to be a demanding and 
difficult process that capacitive organisations such as RODA need to overcome to develop social innovations.

Open Access This chapter is distributed under the terms of the Creative Commons AttributionNonCommercial 4.0 International License (http://creativecommons.org/licenses/by-nc/4.0/), which permits any noncommercial use, duplication, adaptation, distribution and reproduction in any medium or format, as long as you give appropriate credit to the original author(s) and the source, a link is provided to the Creative Commons license and any changes made are indicated.

The images or other third party material in this chapter are included in the work's Creative Commons license, unless indicated otherwise in the credit line; if such material is not included in the work's Creative Commons license and the respective action is not permitted by statutory regulation, users will need to obtain permission from the license holder to duplicate, adapt or reproduce the material.

\section{References}

André, I. (2013). Gender and social innovation: The role of EU policies. In F. Moulaert, D. MacCallum, A. Mehmood, \& A. Hamdouch (Eds.), The international handbook on social innovation: Collective action, social learning and transdisciplinary research (pp. 412-423). Cheltenham: Edward Elgar.

Bežovan, G. (2009). Civilno društvo i javna uprava kao dionici razvoja kombinirane socijalne politike u Hrvatskoj. Hrvatska javna uprava, 9(2), 355-391.

Bežovan, G. (2010). Achievements and challenges of welfare mix development (in Croatian). Zagreb: CERANEO.

Bežovan, G., \& Zrinščak, S. (2001). Mogućnosti decentralizacije u socijalnoj politici i nove uloge lokalnih vlasti. Revija za socijalnu politiku, 8(3-4), 239-258.

Bežovan, G., Matančević, J., \& Baturina, D. (2013). Social innovations in Zagreb. WILCO Publication no. 32. http://www.wilcoproject.eu/wordpress/wp-content/uploads/WILCO_WP3_Zagreb_321.pdf. Accessed 11 April 2014.

Dobrotić, I. (2007). Usklađenost obiteljskog života i rada. In UNDP (Ed.), Kvaliteta života $u$ Hrvatskoj: regionalne nejednakosti (pp. 71-78). Zagreb: UNDP Hrvatska.

Dobrotić, I., Matković, T., \& Baran, J. (2010). Zaposlenost žena i pristup sustavu predškolske skrbi za djecu u Hrvatskoj: postoji li veza? Revija za socijalnu politiku, 17(3), 363-385. doi:10.3935/ rsp.v17i3.924.

Goldsmith, S., Georges, G., \& Burke, T. G. (2010). The power of social innovation. How civic entrepreneurs ignite community networks for good. San Francisco: Jossey-Bass.

Habisch, A., \& Loza Adaui, C. R. (2013). A social capital approach towards social innovation. In T. Obburg \& R. Schmidpeter (Eds.), Social Innovation-Solutions for a sustainable future (pp. 65-74). Berlin: Springer.

Matković, T., \& Dobrotić, I. (2013). Promjene u obuhvatu programima predškolskog odgoja i obrazovanja u Hrvatskoj na nacionalnoj i županijskoj razini između 1990. i 2012. godine. Revija za socijalnu politiku, 20(1), 65-73. doi:10.3935/rsp.v20i1.1133.

Moulaert, F., \& Mehmood, A. (2013). Holistic research methodology and pragmatic collective action. In F. Moulaert, D. MacCallum, A. Mehmood \& A. Hamdouch (Eds.), The international handbook on social innovation: Collective action, social learning and transdisciplinary research (pp. 442-453). Cheltenham: Edward Elgar.

Puljiz, V., \& Bouillet, D. (2003). National family policy. Zagreb: Državni zavod za zaštitu obitelji, materinstva i mladeži.

Zrinščak, S. (2008). Obiteljska politika. In V. Puljiz, G. Bežovan \& T. Matković, Z. Šućur, \& S. Zrinščak (Eds.), Socijalna politika Hrvatske (pp. 279-336). Zagreb: Pravni fakultet. 